\title{
IMPLEMENTASI KONSEP KEADILAN DENGAN SISTEM NEGATIF WETTELIJK DAN ASAS KEBEBASAN HAKIM DALAM MEMUTUS SUATU PERKARA PIDANA DITINJAU DARI PASAL 1 UNDANG-UNDANG NO 4 TAHUN 2004 TENTANG KEKUASAAN KEHAKIMAN
}

(Analisa putusan No.1054/Pid.B/2018/PN.Jkt.Sel )

\author{
1Eldo Pranoto Putra, 2Muhammad Iqbal \\ Fakultas Hukum Universitas Pamulang \\ Email :eldoputra58@gmail.com
}

Received: Juni 2020/Revised: Juli 2020/Accepted: Juli 2020

\begin{abstract}
ABSTRAK
Kekuasaan kehakiman yang merdeka adalah salah satu ciri Negara demokratis, tidak ada Negara yang dapat disebut Negara demokrasi tanpa praktek kekuasaan kehakiman yang merdeka. Akan tetapi terdapat komentar dan pandangan negative terhadap hakim mengenai sejauh mana hakim dapat bekerja dengan obyektif, dan apakah tidak mungkin terjadi bahwa hakim yang dikonstruksikan sebagai manusia bebas dan tidak berpihak tidak akan "bias" dalam memeriksa dan memutus perkara yang dihadapinya, penelitian ini bertujuan untuk mengetahui sejauh mana hakim menggunakan kebebasan serta keyakinannya dalam memutus suatu perkara pidana.
\end{abstract}

Kata kunci : Kekuasaan kehakiman, kehakiman yang merdeka

\begin{abstract}
ABSTRACK
An independent judicial power is one of the characteristics of a democratic state, no country can be called a democratic state without the practice of an independent judicial power. However, there are negative comments and views on judges regarding the extent to which judges can work objectively, and whether it is impossible that judges who are constructed as free and impartial human beings will not be "biased" in examining and deciding the cases they face, this study aims to know the extent to which a judge uses his freedom and confidence in deciding a criminal case
\end{abstract}

Keyword : judicial power, an independent judiciary 


\section{PENDAHULUAN}

Kekuasaan kehakiman yang merdeka (the independence of judiciary) merupakan salah satu ciri terpenting setiap Negara hukum yang demokratis. Tidak ada Negara yang dapat disebut Negara demokrasi tanpa praktek kekuasaan kehakiman yang merdeka. Bahkan oleh mukti arto dikatakan, keberadaan lembaga pengadilan yang merdeka itu sangat penting karena 3 (tiga) alasan (a) pengadilan merupakan pengawal konstitusi; (b) pengadilan bebas merupakan unsur negara demokrasi (c) pengadilan merupakan akar Negara hukum. (Arto, 2001) Akan tetapi terdapat komentar dan pandangan negative terhadap hakim mengenai sejauh mana hakim dapat bekerja dengan obyektif, dan apakah tidak mungkin terjadi bahwa hakim yang dikonstruksikan sebagai manusia bebas dan tidak berpihak, tidak akan "bias" dalam memeriksa dan memutus perkara yang dihadapinya.

Apakah benar bahwa seorang hakim baik secara sadar ataupun tidak sadar tidak akan dipengaruhi oleh sikap "prejudice" (prasangka) yang disebabkan oleh latar belakang social dan politik kehidupannya sendiri dalam memutus setiap perkara yang untuk itu ia diharapkan bersikap obyektif dan imparsial. Sikap "bias" itu terkadang dipengaruhi oleh cara hakim sendiri dalam memahami atau memandang kedudukan dan fungsinya. Hal ini terjadi dalam memutus suatu perkara, pasti ada pihak yang senang dan ada pihak yang tidak senang, termasuk dalam perkara yang bersangkutan antara Negara dan warga Negara. Dalam hal demikian, apakah hakim akan tetap dapat bersikap adil dan netral atau akan merasa menjadi "hero" bagi rakyat dalam menghadapi negara (Arto, 2001)

System pembuktian negatif wettelijk (berdasarkan keyakinan hakim) tercantum dalam pasal 183 KUHAP yang berbunyi sebagai berikut:

"hakim tidak boleh menjatuhkan pidana kepada seseorang kecuali dengan sekurang-kurangnya memiliki 2 (dua) alat bukti yang sah ia memperoleh keyakinan, bahwa suatu tindak pidana benarbenar terjadi dan bahwa terdakwalah yang bersalah melakukannya"

Dalam pasal tersebut terlihat tidaklah cukup hanya alat bukti saja, tetapi juga harus mempunyai keyakinan seorang hakim, sebaliknya juga tak cukup kalau hanya ada keyakinan hakim tanpa bukti-bukti 
Hakim harus berpikir logis dan melakukan penalaran waktu membuktikan, seperti pekerjaan seorang ahli fikir dibidang ilmu pengetahuan. Segala gejala diterangkannya dalam hubungan satu dengan yang lainnya sampai kepada kesimpulan sesuai menurut undang-undang. Fakta yang menunjang keputusannya harus diucapkannya. Tidak perlu dicantumkan semua jalan pikiran hakim dalam keputusannya. Yang diperlukan ialah, bahwa orang yang membaca putusan hakim berdasarkan bahan-bahan yang diberikan akan menarik kesimpulan yang sama dengan kesimpulan hakim dan untuk setiap bagian yang dituduhkan harus ada alat bukti. istem ini memadukan unsur "objektif" dan "subjektif" dalam menentukan salah atau tidaknya terdakwa. Tidak ada yang paling dominan diantara kedua unsur tersebut. Jika salah satu diantara dua unsur itu tidak ada, tidak cukup mendukung keterbuktian kesalahan terdakwa. Misalnya, ditinjau dari segi cara dan dengan alat-alat bukti yang sah menurut undang-undang, kesalahan terdakwa cukup terbukti, tetapi sekalipun sudah cukup terbukti, hakim "tidak yakin" akan kesalahan terdakwa, dalam hal seperti ini terdakwa tidak dapat dinyatakan bersalah, sebaliknya, hakim benar-benar yakin terdakwa sungguhsunguh bersalah melakukan kejahatan yang didakwakan. Akan tetapi, keyakinan tersebut tidak di dukung dengan pembuktian yang cukup menurut cara dan dengan alat-alat bukti yang sah menurut undangundang. Dalam hal seperti ini pun terdakwa tidak dapat dinyatakan bersalah. Oleh karena itu, diantara kedua komponen tersebut harus "saling mendukung" (Harahap, 1985)

Berdasarkan uraian-uraian yang telah dijelaskan diatas, penulis ingin menjelaskan "bagaimanakah seorang hakim dapat memutuskan suatu perkara menggunakan sistem pembuktian negative dengan keyakinan serta dengan asas kebebasan hakim dalam memutuskan suatu perkara dan bagaimanakah bentuk dari suatu batasan yang ditanamkan oleh undang-undang No.4 Tahun 2004 dan UU Dasar 1945 dalam konsep pembuktian negative wettelijk yang dikaitkan dengan kebebasan hakim memutuskan" Berkaitan dengan isu hukum tersebut, maka penulis tertarik untuk mengangkat putusan pengadilan negeri Jakarta selatan dengan nomor putusan NO.1054/Pid.B/2018/PN.Jkt.Sel dan ingin mengambil judul yang diambil oleh penulis, maka penulis tertarik untuk menulis mengangkat penelitian ini dengan judul: IMPLEMENTASI KONSEP KEADILAN DENGAN SISTEM NEGATIVE WETTELIJK DAN ASAS KEBEBASAN HAKIM DALAM MEMUTUS SUATU PERKARA 


\section{PIDANA DITINJAU DARI UNDANG-UNDANG NO 4 TAHUN 2004 TENTANG KEKUASAAN KEHAKIMAN.}

\section{PERMASALAHAN}

Berdasarkan uraian diatas, maka penulis dapat menyimpulkan rumusan masalah sebagai berikut:

1. Bagaimana asas kebebasan hakim dalam konsep kebebasan memutus perkara dalam menciptakan keadilan?

2. Bagaimana bentuk prinsip kebebasan hakim untuk menciptakan keadilan dengan sistem pembuktian negative?

\section{METODE PENELITIAN}

Dalam penulisan ini penulis menggunakan metode penelitian yang dilaksanakan dengan mengumpulkan data dari landasan teoritis dengan mempelajari buku-buku, karya ilmiah, dan artikel-artikel serta sumber bacaan lainnya yang ada hubungannya dengan permasalahan yang diteliti. Serta menganalisis data-data yang diperoleh dari hasil penelitian menggunakan teknik analisa data pendekatan kualitatif, yaitu merupakan tata cara penelitian yang menghasilkan data deskriptif tersebut yaitu sebagai berikut :

1. Pendekatan penelitian

Metode pendekatan yang dilakukan dalam penelitian ini adalah metode pendekatan yuridis normatif yaitu penelitian hukum yang dilakukan dengan cara meneliti bahan pustaka atau data sekunder dengan memahami Hukum sebagai perangkat peraturan atau norma-norma positif di dalam system perundang-undangan yang mengatur mengenai permasalahan dalam penelitian ini.

2. Sumber data

Sumber data yang dipergunakan dalam penelitian ini dapat berwujud data yang diperoleh melalui bahan-bahan kepustakaan dan atau secara langsung dari bahan narasumber. Data yang diperoleh langsung dari narasumber dinamakan data primer. Sedangkan data yang diperoleh melalui bahan kepustakaan disebut data sekunder.

3. Teknis pengumpulan data

Sesuai dengan judul data skripsi ini, maka penelitian ini dilakukan dengan menganalisis isu hukum yang terjadi pada perkara pidana adapun alasan penulis memilih isu ini karena penulis beranggapan bahwa isu ini adalah isu yang menarik untuk ditinjau

4. Teknis analisis data 
Teknis analisis data dilakukan dalam penulisan skripsi ini adalah teknik analisis normatif kuantitatif. Normatif berarti bahwa data yang dianalisis berdasrkan peraturan-peraturan yang relevan sebagai hukum positif. Sedangkan kualitatif yaitu merupakan analisis data tanpa mempergunakan rumusan dan angka.

\section{PEMBAHASAN}

\section{Pengertian kebebasan seorang hakim}

Dalam sistem kekuasaan kehakiman di Indonesia, kata kebebasan digunakan terhadap lembaga peradilan (kekuasaan kehakiman yang merdeka), maupun terhadap hakim (kebebasan hakim) sebagai aparatur inti kekuasaan kehakiman. Istilah kebebasan hakim sebagai suatu prinsip yang telah ditancapkan konstitusi, ternyata dalam tataran implementasi personal maupun social telah banyak menimbulkan berbagai macam penafsiran, ketika kata kebebasan digabungkan dengan kata hakim yang membentuk kata majemuk "kebebasan hakim" maka penafsirannya bermacam-macam. Ada yang menafsirkan bahwa kebebasan hakim merupakan kebiasaan yang tidak bersifat mutlak, karena tugas hakim adalah untuk menegakkan hukum dan keadilan yang harus didasarkan (terikat kepada dasar pancasila) oleh karena itu kebebasan hakim tidak bersifat mutlak, maka kebebasan hakim tidak boleh terlepas dari unsur tanggung jawab. Kebebasan hakim bukanlah kebebasan yang mutlak dan tanpa batas yang cenderung menjurus kepada kesewenang-wenangan. (Budiarto, 1991) Istilah kebebasan dari segi etimologi adalah kata sifat berasal dari kata "bebas", yang berarti merdeka, tak terkendali. Dalam kamus besar Bahasa Indonesia kata "bebas" mempunyai arti lepas sama sekali, dalam arti tidak terhalang, tidak terganggu, sehingga dapat bergerak, berbicara, berbuat, tiaptiap anggota dapat mengungkapkan pendapatnya Secara etimologi makna kebebasan, tidak dapat dipastikan artinya. Kata bebas menggambarkan pada suatu kondisi yang memungkinkan seseorang tidak terikat pada sesuatu hal yang lain, lepas dari kewajiban atau tuntutan yang lain, murni dilakukan oleh dirinya sendiri. Seseorang lebih cenderung menyatakan ia "bebas untuk", dari pada menyatakan ia "bebas dari" sesuatu.

Menurut Bagir Manan, bahwa majelis hakim dipandang menjadi tidak netral atau berpihak karena beberapa hal, antara lain : (Manan, 2004) 


\section{Eldo Pranoto Putra \& Muhammad Iqbal}

a. Pengaruh kekuasaan dimana majelis hakim tidak berdaya menghadapi kehendak pemegang kekuasaan yang lebih tinggi, baik dari lingkungan kekuasaan kehakiman sendiri, maupun dari luar (misalnya dari gubernur, bupati, menteri dan lain-lain)

b. Pengaruh publik. Tekanan publik yang berlebihan dapat menimbulkan rasa takut atau rasa cemas kepada majelis hakim yang bersangkutan sehingga memberikan keputusan yang sesuai dengan paksaan publik yang bersangkutan.

c. Pengaruh pihak. Pengaruh pihak dapat bersumber dan hubungan primordial tertentu, maupun karena komersialisasi perkara. Perkara menjadi komoditas perniagaan, yang membayar lebih banyak akan dimenangkan

\section{Teori keadilan Hukum}

Menurut Hans Kelsen, nilai keadilan bersifat subjektif, sedangkan eksistensi dari nilai-nilai hukum dikondisikan oleh faktafakta yang dapat diuji secara objektif. Keadilan dalam arti legalitas adalah suatu kualitas yang tidak berhubungan dengan isi tata aturan positif, tetapi dengan penerapannya. Keadilan adalah penerapan hukum yang sesuai dengan yang ditetapkan oleh suatu tata hukum. Dengan demikian keadilan berarti mempertahankan tata hukum secara sadar dalam penerapannya. Inilah keadilan berdasarkan hukum (Atmadja, 2013)

Dua prinsip keadilan menurut Rawls

Pertama, adalah prinsip kebebasan yang sama sebesar-besarnya (principle of greatest equal liberty), prinsip ini mencakup :

1. Kebebasan untuk berperan serta dalam kehidupan politik (hak bersuara, hak mencalonkan (diri dalam pemilihan)

2. Kebebasan berbicara (termasuk kebebasan pers)

3. Kebebasan berkeyakinan (termasuk keyakinan beragama)

4. Kebebasan menjadi diri sendiri (person)

5. Hak untuk mempertaruhkan diri pribadi

Kedua, prinsip keduanya ini berprinsip dari dua bagian, yaitu prinsip perbedaan (the diference principle) dan prinsip persamaan yang adil atas kesempatan (the principle of fair equality of opportunity) inti prinsip pertama adalah bahwa perbedaan social dan ekonomis harus diatur agar memberikan manfaat yang paling besar bagi mereka yang paling kurang beruntung. Istilah perbedaan sosiologi dan ekonomis dalam prinsip perbedaan menuju pada ketidak samaan dalam prospek seorang untuk mendapatkan unsur pokok 
kesejahteraan, pendapatan dan otoritas, sedang istilah yang (paling kurang diuntungkan) menunjuk pada mereka yang paling kurang mempunyai peluang untuk mencapai prospek kesejahteraan, pendapatan dan otoritas. (Fattah, 2013)

\section{Pengertian Asas Keadilan}

Asas adalah sesuatu yang menjadi tumpuan berfikir atau berpendapat. Asas juga dapat berarti dasar hukum, asas adalah suatu dalil umum yang dinyatakan dalam istilah umum tanpa mensyaratkan cara-cara khusus mengenal pelaksanaannya yang diterapkan pada serangkaian perbuatan untuk menjadi petunjuk yang tepat bagi perbuatan itu. (Wijayanta, 2014)

Hubungan hukum dan keadilan walaupun sifat dasarnya abstrak, seolah-olah hanya menjadi ruang lingkup telaah filsafat. Tetapi kelesatarian sebagai relafansi antara hukum dan keadilan selalu terjaga. Lintasan sejarah dari seluruh aliran pemikiran dalam ilmu hukum senantiasa memperjuangkan keadilan, entah dari sudut pandang manapun caranya memandang hukum, baik hukum dipandang sebagai objek, maupun hukum dipandang sebagai bagian dari subjek yang melekat dalam diri personal. Harus diakui segala analisis, pembongkaran, dekonstruksi, hingga kritik terhadap hukum dalam tataran implementatif semuanya terikat dengan kehendak untuk mewujudkan hukum dalam tujuannya untuk mencapai keadilan (Aristoteles, Syamsur Irawan Kharie, 2007)

Kemudian aristoteles memaparkan arti dari asas keadilan dan membagi secara proporsional yang terbagi menjadi keadilan distributif, keadilan kumutatif, dan keadilan vendikatif:

1. Keadilan distributif (justitia distributive) keadilan yang secara proporsional diterapkan dalam lapangan hukum publik secara umum

2. Keadilan komutatif keadilan dengan mempersamakan antara prestasi dan kontraprestasi

3. Keadilan vendikatif keadilan dalam hal menjatuhkan hukuman atau ganti kerugian dalam tindak pidana. Seseorang dianggap adil apabila ia dipidana badan atau denda sesuai besarnya hukuman yang telah ditentukan atas tindakan pidana yang dilakukannya

\section{Hukum Sebagai Implementasi Keadilan}

Politik hukum adalah bagian dari ilmu hukum yang mengurai atau membahas tentang perbuatan aparat berwenang dalam memilih 


\section{Eldo Pranoto Putra \& Muhammad Iqbal}

beberapa alternative yang sudah tersedia untuk menciptakan produk hukum guna mewujudkan tujuan negara. Berdasarkan definisi politik hukum tersebut, terdapat empat unsur untuk memenuhi syarat politik hukum. Unsur-unsur tersebut adalah sebagai berikut:

1. Harus ada perbuatan aparat yang berwenang

2. Harus ada alternatif yang disediakan (dalam bentuk hukum) oleh negara untuk dipilih

3. Harus ada produk hukum baru yang lahir (menciptakan produk hukum) termasuk produk hukum hasil perubahan

4. Harus ada tujuan Negara yang diwujudkan

Hukum bukan merupakan tujuan, tetapi sarana atau alat untuk mewujudkan tujuan Negara (Mertokusumo, 2008), aparat yang berwenang mencerminkan kekuasaan.Setiap aparat memiliki fungsi yang memberikan kewenangan. Kewenangan melahirkan hak-hak kepada aparatur negara. Di dalam kekuasaan itu sendiri,terdapat fungsi timbal balik antara hukum dan kekuasaan, yaitu kekuasaan memiliki fungsi terhadap hukum, dan hukum juga memiliki fungsi terhadap kekuasaan Terdapat tiga macam fungsi kekuasaan terhadap hukum yaitu :

1. Kekuasaan merupakan sarana membentuk hukum

2. Kekuasaan merupakan alat untuk membentuk hukum

3. Kekuasaan sebagai media mengeksekusi putusan hakim

Begitu dengan sebaliknya, terdapat 3 macam fungsi hukum terhadap kekuasaan, yaitu :

1. Hukum sebagai media melegalisasi kekuasaan

2. Hukum berfungsi mengatur dan membatasi kekuasaan

3. Hukum berfungsi meminta pertanggung jawaban kekuasaan

Teori pembuktian yang berlaku di Indonesia menurut hukum acara pidana

Pembuktian tentang benar atau tidaknya dan terbukti atau tidak terbuktinya terdakwa melakukan seperti termuat yang ada pada surat dakwaan yang dibuat oleh jaksa penuntut umum, dalam proses ini hak asasi manusia menjadi sangat penting. Maka dari itu ada beberapa teori pembuktian untuk membuktikan perbuatan yang didakwakan, sistem teori pembuktian ini bervariasi menurut waktu dan tempat, yaitu :

a. Sistem atau teori undang-undang berdasarkan hukum positif (Positief Wettelijk Bewijs Theorie) 
Pembuktian yang didasarkan melalui kepada alat-alat pembuktian yang disebut undang-undang, disebut sistem atau teori pembuktian berdasarkan undang-undang secara positif (Positief Wettelijk Bewijs Theorie). Dikatakan secara positif, karena hanya didasarkan kepada undang-undang. Sistem atau teori pembuktian berdasar undang-undang secara positif ini berusaha untuk menyingkirkan semua pertimbangan subjektif hakim dan mengikat hakim secara ketat menurut peraturan-peraturan pembuktian yang keras, dianut di Eropa pada waktu berlakunya asas inkisitor (inquisitoir) dalam acara pidana, namun Teori pembuktian ini ditolak oleh Wirjono Prodjodikoro untuk dianut dia Indonesia, karena katanya bagaimana hakim dapat menetapkan kebenaran selain dengan cara menyatakan kepada keyakinannya tentang hal kebenaran itu, lagi pula keyakinan seorang hakim yang jujur dan berpengalaman mungkin sekali adalah sesuai dengan keyakinan masyarakat.

b. Sistem pembuktian menurut keyakinan hakim (Conviction Intime/Conviction Raisonce)

Pembuktian ini disebut juga conviction intime. Disadari bahwa alat berupa pengakuan terdakwa sendiri pun tidak selalu membuktikan kebenaran. Pengakuan pun kadang-kadang tidak menjamin terdakwa benar-benar telah melakukan perbuatan yang didakwakan. Oleh karena itu, diperlukan bagaimanapun juga keyakinan hakim sendiri. Manurut Wirjono Prodjodikoro,mengemukakan : Sistem pembuktian demikian pernah dianut di Indonesia, yaitu pada pengadilan distrik dan pengadilan kabupaten. Sistem ini memungkinkan hakim menyebut apa saja yang menjadi dasar keyakinannya, misalnya keterangan medium atau dukun. Sistem ini memberi kebebasan kepada hakim terlalu besar, sehingga sulit diawasi. Disamping itu, terdakwa atau penasihat hukumnya sulit untuk melakukan pembelaan. Dalam hal ini hakim dapat memidana terdakwa berdasarkan keyakinannya bahwa ia telah melakukan apa yang didakwakan. Sistem atau teori pembuktian berdasar keyakinan hakim atas alasan yang logis (laconviction raisonnee)

c. Sistem pembuktian berdasarkan keyakinan hakim menurut alasan yang logis (Laconviction Raisonnee) 


\section{Eldo Pranoto Putra \& Muhammad Iqbal}

Pembuktian ini mempunyai konsep bahwa hakim dapat memutuskan kepada dasar-dasar pembuktian disertai dengan suatu kesimpulan (concluise) yang berlandaskan kepada peraturan-peraturan tertentu jadi putusan hakim dijatuhkan dengan suatu motivasi, sistem teori ini dapat dikatakan pembuktian bebas karena hakim dapat bebas menyebutkan alasan-alasan keyakinannya ( vrije bewijstheorie)

d. Teori pembuktian berdasarkan undang-undang secara negatif (Negatief Wettelijke Bewijs Theorie)

HIR maupun KUHAP, begitu pula Ned. Sv. Yang lama dan yang baru, semuanya menganut sistem atau teori pembuktian berdasarkan undang-undang negatif. Pasal 183 KUHAP mengatur bahwa "Hakim tidak boleh menjatuhkan pidana kepada seorang, kecuali apabila dengan sekurang-kurangnya dua alat bukti yang sah ia memperoleh keyakinan bahwa suatu tindak pidana benarbenar terjadi dan bahwa terdakwalah yang bersalah melakukannya.

Pasal 185 ayat (2) KUHAP mengatakan bahwa keterangan seorang saksi saja tidaklah cukup untuk menganggap kesalahan terdakwa telah terbukti. Ini disebut bukti minimum. Penjelasan Pasal 183 KUHAP mengatakan bahwa ketentuan ini adalah untuk menjamin tegaknya kebenaran, keadilan, dan kepastian hukum bagi seorang. Berdasarkan undang-undang pengakuan terhadap teori pembuktian hanya berlaku untuk keuntungan terdakwa, tidak dimaksudkan untuk menjurus kepada dipidananya orang yang tidak bersalah hanya dapat kadang-kadang memaksa dibebaskannya orang bersalah.

\section{Fungsi Persidangan}

Persidangan dapat diartikan sebagai sarana yang digunakan untuk memusyawarahkan suatu masalah untuk mendapatkan suatu keputusan resmi dan berjalan sesuai peraturan yang berlaku. Mungkin secara garis besar, berdasarkan pengertian tersebut telah terlihat fungsi dari pelaksanaan persidangan. Fungsi utama persidangan adalah untuk sebagai sarana menyelesaikan suatu perrmasalahan dan menetapkan keputusan yang tepat untuk menangani masalah tersebut. Atau dengan kata lain sebagai sarana untuk mencari solusi dalam memecahkan suatu permasalahan. Namun secara lebih detail terdapat beberapa fungsi persidangan. 


\section{Asas-Asas Dalam Persidangan}

1. Asas pemeriksaan hakim yang langsung dan lisan

Pemeriksaan dalam sidang di pengadilan dilakukan oleh hakim secara langsung, arti langsung di sini adalah langsung kepada terdakwa dan para saksi. Hal tersebut sangat berbeda dengan acara perdata yang di mana tergugat dapat diwakili oleh kuasanya. Pemeriksaan oleh hakim juga dapat dilakukan secara lisan, artinya bukan tertulis sebagaimana antara hakim dan terdakwa. Dasar hukum mengenai ketentuan di atas diatur dalam Pasal 154,155 KUHAP, dan seterusnya

Dari asas langsung tersebut yang dipandang sebagai pengecualian ialah kemungkinan dari putusan hakim yang dijatuhkan tanpa hadirnya terdakwa sendiri yaitu putusan verstek (putusan tanpa kehadiran tergugat) atau in absentia (upaya mengadili tanpa dihadiri terdakwa) Perlu digaris bawahi bahwa ini merupakan pengecualian yaitu dalam acara pemeriksaan perkara pelanggaran lalu lintas jalan 19 yang diatur dalam Pasal 213 KUHAP berbunyi : "terdakwa dapat menunjuk seseorang dengan surat untuk mewakilinya di sidang"

Begitu pula ketentuan yang ada dalam Pasal 214 KUHAP yang mengatur tentang acara pemeriksaan verstek tersebut. Ada pula dalam Hukum Acara Pidana khusus seperti Undang-Undang Nomor 7 (Darurat) Tahun 1955 tentang Tindak Pidana Ekonomi, dan dalam Undang-Undang Nomor 31 Tahun 1999 tentang Pemberantasan Tindak Pidana Korupsi, dikenal pemeriksaan pengadilan secara in absentia atau tanpa hadirnya terdakwa (Hamzah, 1996)

2. Asas fair, impartial, impersonal and objective (peradilan yang cepat, sederhana, dan biaya ringan, serta bebas, jujur, dan tidak memihak)

Termuat dalam pasal 2 ayat 4 undang-undang Nomor 48 Tahun 2009 tentang kekuasaan kehakiman yang menyatakan bahwa : "peradilan dilakukan dengan sederhana, cepat, dan biaya ringan"

"sederhana" disini artinya adalah pemeriksaan dan penyelesaian perkara dilakukan dengan cara efisien dan efektif, "biaya ringan" artinya adalah biaya perkara yang dapat dijangkau oleh masyarakat banyak. (Bakri, 2011) istilah "cepat" sendiri diartikan "segera" peradilan cepat sangat diperlukan terutama untuk 


\section{Eldo Pranoto Putra \& Muhammad Iqbal}

menghindari penahanan yang lama sebelum adanya keputusan hakim, hal tersebut tidak boleh lepas dari perwujudan hak asasi manusia. Begitu pula dengan peradilan bebas yang jujur, dan tidak memihak

pihak manapun sebagaimana ditonjolkan dalam undang-undang tersebut. (Hamzah, 1996)

\section{Asas keterbukaan (sidang/terbuka untuk umum)}

Pada prinsipnya, semua persidangan harus dinyatakan terbuka untuk umum, kecuali hal yang diatur dalam undang-undang. Perlu digaris bawahi sebelumnya, dinyatakan dengan tegas bahwa yang diartikan terbuka untuk umum adalah pemeriksaan pengadilannya, jadi pemeriksaan pendahuluan, penyidikan, dan praperadilan tidak terbuka untuk umum. (Bakri, 2011)

Selanjutnya, di dalam Pasal 153 ayat (3) KUHAP menyebutkan bahwa untuk keperluan pemeriksaan hakim ketua sidang membuka sidang dan menyatakan terbuka untuk umum, kecuali dalam perkara mengenai kesusilaan atau terdakwanya anak-anak. (Hamzah, 1996)

4. Asas equality before the law (persamaan dimata hukum)

Yang dimaksud adalah perlakuan yang sama atas diri setiap orang di muka hukum dengan tidak membedakan latar belakang sosial, ekonomi, keyakinan politik, agama, golongan, dan sebagainya. (Widiartana, 2005) Yang dimaksud perlakuan yang sama atas diri setiap orang di muka hukum dengan tidak mengadakan pembedaan perlakuan adalah bahwa di depan pengadilan kedudukan semua orang sama, maka mereka harus diperlakukan sama. Ketentuan atas asas tersebut dinyatakan dalam pasal 4 ayat 1 Undang-undang No. 48 Tahun 2009 tentang Kekuasaan Kehakiman menentukan bahwa, "Pengadilan mengadili menurut hukum dengan tidak membedabedakan orang". Tujuan dari asas ini adalah agar memberikan jaminan kepada hak -hak asasi manusia yang mendapat perlindungan didalam negara yang berdasarkan Pancasila. Hal ini memberikan suatu jaminan hukum bagi siapa saja yang melakukan pelanggaran atau perbuatan tindak pidana yang memungkinkan sanksi hukum bagi yang melakukannya baik itu dilakukan oleh pejabat negara atau masyarakat biasa, apabila mereka melakukan perbuatan hukum. Maka digunakan sanksi hukum sesuai dengan hukum yang berlaku. Ada juga untuk asas ini juga sering dipakai bahasa Sansekerta "tan hana dharma manrua" yang dijadikan motto Persaja (Persatuan Jaksa). (Hamzah, 1996) 


\section{Analisa Putusan}

Dari uraian kasus yang dikutip diatas, tampak bahwa dasar dari setiap putusan hakim adalah dakwaan dari jaksa penuntut umum. Hakim dalam pertimbangan putusannya ternyata tidak keluar dari pasal tindak pidana yang menjadi dakwaan jaksa penuntut umum, meskipun dakwaan itu disusun dengan berbagai bentuk surat dakwaan. Akan tetapi dalam mengambil putusan terhadap kasus konkrit tampak hakim mempunyai kebebasan untuk menentukan dakwaan mana yang tepat untuk diterapkan atau tidak diterapkan sesuai dengan jenis putusan yang ditentukan oleh hukum acara. Dalam kasus tersebut, penuntut umum menyusun dakwaan alternative yang didakwakan oleh terdakwa dengan ketentuan yaitu kesatu pasal $378 \mathrm{KUHP}$, kedua pasal $372 \mathrm{KUHP}$, atau ketiga pasal 368 ayat (1) KUHP. Hakim pengadilan negeri Jakarta selatan berdasarkan pertimbangannya menyatakan terbukti dakwaan kesatu yaitu tindak pidana penipuan

Dari kasus ini terbukti, bahwa hakim dapat memilih/menentukan bahwa pasal mana yang terbukti kuat guna membuktikan pasal yang pas untuk menjerat terdakwa. Apabila hakim berpendapat berdasarkan penilaian bukti-bukti yang sah dapat menyatakan terbukti atau tidaknya, disini hakim tampak mempunyai kebebasan menentukan pilihan, dakwaan mana yang terbukti berdasarkan hasil pembuktian di persidangan dan dakwaan mana pula yang tidak terbukti dengan membebaskan terdakwa dari dakwaan tersebut. Dari sini bisa diambil kesimpulan bahwa hakim tidak dapat memberikan putusan terhadap perbuatan yang tidak didakwakan jaksa penuntut umum, hakim hanya mengambil putusan dengan membebaskan terdakwa dari dakwaan yang tidak terbukti tersebut dan tidak akan menghukum dengan perbuatan yang tidak didakwakan. Disini hakim tidak lagi dipandang sebagai corong undang-undang, tetapi sebagai pembentuk hukum yang secara mandiri memberi bentuk kepada isi undang-undang dan menyesuaikannya dengan kebutuhan-kebutuhan, pandangan ini disebut juga dengan pandangan materiil yurudis atau otonom

Hal ini selaras dengan ketentuan Pasal 5 Ayat (1) UU No. 4 Tahun 2004 yang berbunyi: Pengadilan mengadili menurut hukum dengan tidak membedakan orang. Pengertian "menurut hukum" adalah lebih luas dari pada menurut undang-undang, sehingga membuka peluang bagi hakim untuk melaksanakan kebebasan yang 


\section{Eldo Pranoto Putra \& Muhammad Iqbal}

sebebas-bebasnya, sebaliknya pengertian menurut undang-undang lebih membatasi kebebasan hakim (Mertokusumo S. , 2011)

Untuk menganalisa bagaimana kebebasan hakim dalam menerapkan hukum pidana dalam putusannya, terlebih dahulu akan diuraikan substansi dari suatu putusan hakim itu, proses pengambilan putusan hakim substansinya menurut Mudzakkir memenuhi beberapa hal :

a. Fakta empirik yakni perbuatan orang (subjek hukum) yang melanggar aturan hukum

b. Peraturan hukum yang dijadikan dasar untuk memutus suatu perkara

c. Legal reasoning yakni proses penarikan fakta empiric sebagai dasar untuk melakukan dugaan atau dakwaan (factual guilt) menjadi fakta hukum (legal guilt) atau proses penerapan hukum yang terkait dengan hukum formil dan hukum materil, idealnya menggunakan ilmu pengetahuan hukum dan

d. Kesimpulan hukum atau dictum yang merupakan hasil pengujian dari fakta social non hukum menjadi fakta hukum

Dari 4 (empat) faktor pengambilan putusan hakim tersebut maka focus pembahasan kebebasan hakim disini adalah faktor ketiga yaitu legal reasoning. Bagaimana kebebasan hakim dalam menerapkan hukum terkait dengan hukum pidana materil yang menganut asas legalitas, pola berfikir (legal reasoning) disini sudah mengarah kepada creating, knowledge yang berarti hakim dalam proses pengambilan putusan menggunakan ilmu pengetahuan sebagai alat untuk membentuk atau menafsirkan hukum sesuai dengan wewenangnya di bidang hukum materil atau atas dasar ilmu pengetahuan hukum hakim melakukan inovasi hukum dalam menyelesaikan suatu perkara.

\section{Kebebasan Hakim Dalam Memberikan Vonis Pidana}

Jika hakim dalam pertimbangan hukum putusannya menyatakan semua unsur tindak pidana yang didakwakan jaksa penuntut umum telah terpenuhi, dan ia telah memperoleh keyakinan berdasarkan minimal pembuktian menurut pasal 183 KUHAP, maka hakim menyatakan terdakwa telah terbukti melakukan tindak pidana sesuai dengan surat dakwaan. Terhadap perbuatan terdakwa yang dinyatakan terbukti tersebut, dipertimbangkan pula apakah terdakwa bersalah dan dapat dipertanggungjawabkan perbuatannya, apabila hakim merasa yakin dan berpendapat bahwa terdakwa bersalah 
melakukan tindak pidana yang didakwakan kepadanya, maka hakim pengadilan akan menjatuhkan pidana. Mengenai pidana yang akan dijatuhkan kepada terdakwa yang terbukti bersalah melakukan tindak pidana hukum pidana positif Indonesia memberi kebebasan kepada hakim untuk menentukannya, kebebasan yang diberikan oleh undang-undang kepada hakim itu meliputi jenis pidana seperti ukuran/lamanya pidana yang dijatuhkan dan pelaksanaan pidana tersebut.

Sebagaimana telah diuraikan, bahwa hakim memiliki kebebasan yang sangat luas untuk memilih jenis pidana (strafsoor) yang dikehendaki, sehubungan dengan penggunaan sistem alternatif dalam pencantuman sanksi pidana dalam KUHP. Sebagian besar perumusan delik ada yang pilihannya dua, misalnya pidana penjara atau denda, ada pula mempunyai tiga pilihan yaitu pidana penjara pidana kurungan atau denda dan ada yang hanya satu pilihan seperti pidana penjara saja. Dalam hal ini pilihan salah satu jenis pidana akan menutup kemungkinan untuk memilih yang lain. Akan tetapi delik-delik diluar KUHP misalnya undang-undang korupsi digunakan sekaligus sistem alternatif dan kumulatif dalam rumusan ancaman pidananya.

Disamping kebebasan diatas, hakim juga mempunyai kebebasan pula untuk memilih berat ringannya pidana (strafmaat), yang akan dijatuhkan sebab aturan pemidanaan (straftoemetingstelsel) yang ada hanya menentukan minimum umumnya misalnya pidana penjara atau kurungan satu hari kemudian maksimum umumnya misalnya untuk pidana penjara lima belas tahun yang dapat menjadi dua puluh tahun untuk hal-hal tertentu. Didalam undang-undang khusus diluar KUHP telah diatur tentang minimum khusus dalam penjatuhann pidana selain pengaturan maksimum umum hakim didalam putusannya akan bergerak dalam putusannya dari minimum umum atau minimum khusus sampai kepada maksimum umum sesuai dengan kebebasannya selain itu masih ada lagi kebebasan pada hakim untuk menentukan cara bagaimana pidana tersebut akan dilaksanakan (strafmodus atau strajnodaliteit) misalnya dengan menerapkan pasal 14 a sampai dengan pasal $14 \mathrm{f}$ KUHP yang mengatur pidana bersyarat (voorwaardeelijke veroordeling)

Adapun Tujuan hakim menggunakan kebebasannya untuk menentukan pilihan menjatuhkan pidana sesungguhnya ada tujuaan dari pemidanaan itu sendiri, adapun tujuan-tujuan pemidanaan itu antara lain : 
1. Tujuan perbaikan moral

Adanya ketidakadilan yang terjadi menandakan bahwa ada yang bermasalah dengan sistem hukum, dimana dipahami bahwa sistem hukum adalah sekumpulan jaringan kerja yang sengaja dibuat untuk tujuan tertentu dan jika dikaitkan dengan sistem peradilan pidana berarti ada banyak struktur didalamnya, seperti polisi, jaksa, hakim. Untuk membatasi analisisnya penulis fokus pada hakim, dimana hakim dalam KUHP Pasal 1 adalah pejabat peradilan negara yang diberi wewenang oleh undang-undang untuk mengadili

Dengan demikian dapat dipahami esensi dari moral itu sendiri adalah sebagai berikut :

a. Moral sebagai ajaran kesusilaan, berarti segala sesuatu yang berhubungan dengan tuntutan untuk melakukan perbuatanperbuatan baik dan meningalkan perbuatan jelek yang bertentangan dengan ketentuan yang berlaku dalam suatu masyarakat

b. Moral sebagai aturan, berarti ketentuan yang digunakan oleh masyarakat untuk menilai perbuatan seseorang apakah termasuk baik atau buruk.

c. Moral sebagai gejala kejiwaan yang timbul dalam bentuk perbuatan, seperti berani, jujur, sabar, gairah dan sebagainya

2. Tujuan kemanfaatan

Dengan tujuan ini memandang pidana sebagai suatu yang dapat digunakan untuk mencapai kemanfaatan, baik yang berkaitan dengan orang yang bersalah misalnya menjadikan sebagai orang yang lebih baik maupun yang berkaitan dengan dunia misalnya dengan mengisolasi dan memperbaiki penjahat atau mencegah penjahat potensial akan menjadikan dunia menjadi tempat yang lebih baik agar memberikan kebahagiaan yang sebesar-besarnya dan sebanyak-banyaknya bagi masyarakat. Penanganannya didasarkan pada filsafat sosial, bahwa setiap warga masyarakat mencari kebahagiaan, dan hukum merupakan salah satu alatnya

3. Tujuan asimilasi

Asimilasi adalah proses pembinaan narapidana dan anak didik pemasyarakatan yang dilaksanakan dengan membaurkan narapidana dan anak didik pemasyarakatan dalam kehidupan 
masyarakat. Pandangan asimilasi tersebut mengajarkan adanya kemungkinan untuk mengadakan artikulasi terhadap pemidanaan yang mengintregasikan beberapa fungsi sekaligus "retribution" dan yang bersifat "utilitarian" misalnya pencegahan dan rehabilitasi yang semuanya dilihat sebagai sasaran-sasaran yang harus dicapai oleh suatu rencana pemidanaan. Pidana dan pemidanaan terdiri dari proses kegiatan untuk dapat mengasimilasikan kembali narapidana kedalam masyarakat secara serentak masyarakat menuntut agar memperlakukan individu tersebut dengan suatu yang juga dapat memuaskan permintaan atau kebutuhan pembalasan. Lebih lanjut diharapkan bahwa perlakuan terhadap pelaku tindak pidana tersebut dapat menunjang tujuan-tujuan bermanfaat

\section{KESIMPULAN}

Berdasarkan permasalahan dan hasil penelitian tentang "implementasi konsep keadilan dengan sistem negative wettelijck dan asas kebebasan hakim dalam memutus suatu perkara pidana ditinjau dari undang-undang No 4 tahun 2004 tentang kekuasaan kehakiman" maka dapat ditarik beberapa kesimpulan sebagai berikut:

Pertama, Asas kebebasan hakim dalam mengambil putusan perkara pidana No.1054/Pid.B/2018/PN.Jkt.Sel yaitu serangkaian tindakan untuk menerima, memeriksa dan memutus perkara pidana berdasarkan asas bebas, jujur dan tidak memihak di sidang pengadilan. Kepada hakim selalu dituntut memberikan putusan sebenar-benarnya dan seadil-adilnya Dengan kebebasannya untuk menjatuhkan pidana hakim tentunya tidak dapat terlepas dari pemikiran pribadinya tidak dapat terlepas dari pandangannya tentang segala sesuatu yang berhubungan dengan hakikat pemidanaan, ada yang berpandangan pidana itu tidak perlu dijatuhkan terhadap terdakwa, pidana dijatuhkan tetapi tidak terlalu berat, pidana perlu dijatuhkan agar ada pembalasan, pidana dijatuhkan agar untuk menyadarkan terdakwa dan masyarakat juga jadi mempunyai rasa aman dan sebagainya. Dalam konteks Hakim menegakkan keadilan maka berdasarkan ketentuan Pasal 2 ayat (4), Pasal 4 ayat (2) UU Kekuasaan Kehakiman ditentukan, "peradilan dilakukan demi keadilan berdasarkan Ketuhanan Yang Maha Esa". Konsekuensi aspek ini maka Hakim dalam memutus perkara tidak boleh hanya bersandar pada UU semata, akan tetapi juga harus sesuai dengan hati nuraninya. Kemudian dalam konteks Hakim sebagai penegak hukum 


\section{Eldo Pranoto Putra \& Muhammad Iqbal}

hendaknya Hakim dalam mengadili perkara selain bersandar kepada UU juga bertitik tolak kepada norma-norma yang hidup dalam masyarakat sehingga putusan yang dihasilkan berdimensi keadilan. Pada proses peradilan dengan Hakim sebagai titik sentral inilah yang menjadi aspek utama dan krusial seorang Hakim dalam menggapai keadilan

Kedua, Keyakinan hakim dalam memutus suatu perkara terhadap unsur-unsur pasal perbuatan pidana yang menjadi dakwaan jaksa penuntut umum pada putusan No.1054/Pid.B/2018/PN.Jkt.Sel telah sesuai dengan ketentuan hukum acara pidana (KUHAP) karena hakim mampu untuk menentukan pilihan secara rasional dan relevan menurut ilmu pengetahuan hukum dan serta keyakinan hakim berdasarkan pengetahuannya tersebut guna untuk menegakkan kebenaran dan keadilan.

\section{SARAN}

1. Kebebasan Hakim tidak boleh terpengaruh dengan keadaan di sekelilingnya atau tekanan dari siapa pun dalam mengeluarkan putusan. Hakim harus menjauhkan diri dari keadaan yang dapat memengaruhi mereka di dalam menegakkan keadilan, baik di dalam pengadilan ataupun di luar pengadilan

2. Hakim dalam membuat putusan, seorang hakim sepatutnya dalam menimbang dan memutus suatu perkara dengan memperhatikan asas keadilan, kepastian hukum dan kemanfaatan agar putusan yang dikeluarkan menjadi putusan yang ideal.

\section{DAFTAR PUSTAKA}

\section{Buku}

A Mukti Arto, 2001, konsepsi ideal mahkamah agung, Yogyakarta : Pustaka pelajar.

Aloysius Wisnubroto dan G. Widiartana, 2005, Pembaharuan Hukum Acara Pidana. Bandung : Citra Aditya Bakti.

Andi Hamzah, 1996, Hukum Acara Pidana Indonesia, Jakarta : Sapta Artha Jaya.

Aristoteles, 2007, La Politica, penerjemah Syamsyur Irawan Kharie. Jakarta .

Bagir Manan, 2004, Sistem Peradilan Berwibawa Suatu Pencarian, Jakarta: FH-UI Press. 
I Dewa Gede Atmadja, 2013, Filsafat Hukum, Malang : Setara Press.

Iqbal, M., Susanto, S., \& Sutoro, M. (2019). Efektifitas Sistem Administrasi E-Court dalam Upaya Mendukung Proses Administrasi Cepat, Sederhana dan Biaya Ringan di Pengadilan. Jurnal Ilmu Hukum, 8(2), 302-315.

Iqbal, M., Susanto, S., \& Sutoro, M. (2020, June). E-COURT DALAM TANTANGAN MENEKAN POTENSI KORUPSI DI PENGADILAN. In PROCEEDINGS (Vol. 1, No. 1).

Susanto, S., \& Iqbal, M. (2020, February). Dinamika Penegakan Hukum Pada Konteks Keterbukaan Informasi Keuangan Partai Politik. In Proseding Seminar Nasional Akuntansi (Vol. 2, No. $1)$.

M. Bakri, 2011, Pengantar Hukum Indonesia. Malang: UB Press.

M. Yahya Harahap, 1985, Pembahasan Permasalahan dan Penerapan KUHAP Pemeriksaan Sidang Pengadilan, Banding, Kasasi, dan Peninjauan Kembali, Jakarta : Sinar Grafika.

Miriam budiarto,1991, aneka pemikiran tentang kuasa dan wibawa, Jakarta : sinar harapan.

Mudzakkir, Korban Kejahatan dun Viktimisasi Sekunder OIeh Sistem (Secondary Victimization By The Systern), DaIam Perspektif ukbm Pidana, rnakalah pada Seminar dan Work Shop, Lembaga Bantuan' Hukum (LBH), Yogyakarta

Sudikno Mertokusumo, 2008, Mengenal Hukum Suatu Pengantar, Yogyakarta : Liberty.

Sudikno Mertokusumo, 2011, Teori hukum, Jakarta: Sinar Grafika.

\section{Artikel Seminar/Jurnal/Website}

Fattah, D.Teori keadilan menurut john rawls. Jurnal Tapis, Teropong Aspirasi Politik Islam, 2013

Wijayanta, T. Asas Kepastian Hukum, Keadilan dan Kemanfaatan dalam Kaitannya dengan Putusan Kepailitan Pengadilan Niaga. Jurnal Dinamika Hukum, 14 volume 22014 